\title{
Orange and Passion Fruit Wastes Characterization, Substrate Hydrolysis and Cell Growth of Cupriavidus necator, as Proposal to Converting of Residues in High Value Added Product
}

\author{
GABRIEL O. LOCATELLI ${ }^{1,2}$, LEANDRO FINKLER ${ }^{1}$ and CHRISTINE L.L. FINKLER ${ }^{1}$
}

\author{
${ }^{1}$ Universidade Federal de Pernambuco/UFPE, Centro Acadêmico de Vitória, Rua Alto do \\ Reservatório, s/n, Bela Vista, 55608-680 Vitória de Santo Antão, PE, Brazil \\ ${ }^{2}$ Centro Universitário Brasileiro/UNIBRA, Núcleo de Nutrição, Rua Padre Inglês, 257, Boa Vista, 50050-230 Recife, PE, Brazil
}

Manuscript received on January 23, 2018; accepted for publication on June 18, 2018

\begin{abstract}
How to cite: LOCATELLI GO, FINKLER L AND FINKLER CLL. 2019. Orange and Passion Fruit Wastes Characterization, Substrate Hydrolysis and Cell Growth of Cupriavidus necator, as Proposal to Converting of Residues in High Value Added Product. An Acad Bras Cienc 91: e20180058. DOI 10.1590/0001-3765201920180058.

Abstract: Brazil is the world's largest producer of orange and passion fruit, which are destined mainly for industrialization, generating grand volumes of wastes. The solid portion of these residues is a rich source of pectin - composed mainly of galacturonic acid and neutral sugars, which through the hydrolysis process can be used in biological conversion processes, as the production of polyhydroxyalkanoates (PHAs). This way, we characterized these wastes, followed by the extraction and hydrolysis of pectin for employ as a substrate for the cell growth of Cupriavidus necator. The results confirmed the large portion of pectin (almost $40 \mathrm{~g} .100 \mathrm{~g}^{-1}$ ) and soluble sugars, present in these wastes. The hydrolyzed extract showed as a good source of carbon for the cell growth of $C$. necator with $\mathrm{Y}_{\mathrm{X} / \mathrm{S}} 0.56$ and $0.44, \mu_{\mathrm{Max}} 0.27$ and 0.21 for orange and passion fruit wastes respectively, similar to other carbon sources. This way, the extraction and hydrolysis of orange and passion fruit wastes for the cellular growth of $C$. necator, can be a good alternative to converting of residues in high value added product.
\end{abstract}

Key words: Biological conversion processes, enzymatic hydrolyses, orange wastes, passion fruit wastes, pectin, polyhydroxyalkanoates.

\section{INTRODUTION}

The increase in world population and the awareness of a healthier lifestyle have enhanced the fruit and vegetables consumption. In this scenario, Brazil stands out between the major producers of fruits and juices, being the world's largest producer of oranges (17,251,291 tons) and passion fruit (703,489 tons) in 2016 (IBGE 2016).

Correspondence to: Gabriel Olivo Locatelli

E-mail: gabriel_locatelli@hotmail.com

ORCid: https://orcid.org/0000-0002-5109-7485
The majority of these fruits are harvested and destined to industrialization, and by-products resulting from the processing of orange and passion fruit represent approximately 50\% (DarrosBarbosa and Curtolo 2005, Garcia-Castello et al. 2011) and 75\% (Ferrari et al. 2004) of fruit weight, respectively.

The solid portion of these residues is made of peels, seeds and unused flesh that are commonly wasted, discarded or used in applications of low economic interest. Pectin represents more than $40 \%$ of this material in orange and passion fruits, and others compounds are present such as soluble sugars, 
carbohydrates and fibers (Pinheiro 2007, Rivas et al. 2008, Rezzadori et al. 2012). For instance, there is the potential use of their by-products as substrates in biotechnological processes, such as the production of polyhydroxyalkanoates (PHAs).

PHAs are biodegradable polymers and present properties similar to petroleum derived plastics. They are biodegradable, eco-friendly manufacturing processes and could be used in biomedical applications and to produce consumable goods (Castilho et al. 2009, Anjum et al. 2016). The potential applications of PHA include packaging films, disposable items and controlled drug release systems, covering areas such as medicine, agriculture, tissue engineering and nanocomposites.

Polyhydroxyalkanoates are thermoplastic polyesters of carboxylic acids composed primarily of R-3-hydroxyalkanoic acids which are synthesized in the form of inclusion bodies ("granules") and used as carbon and energy reserves during unbalanced growth by many bacteria. Cupriavidus necator is the most studied species for the industrial production of PHAs and can accumulate this biopolymer to levels up to $80 \%$ of the cellular dry weight from different substrate sources (Ramsay 1994, Lai et al. 2005, Wang et al. 2014).

However, the low productivity and high costs compared to the traditional mineral-based plastics remains an obstacle for the extensive industrial application of PHAs. Their production is still 5 to 10 times more expensive than chemically synthesized polymers, and the substrate may represent more than $40 \%$ of the cost of production (Poirier et al. 1995, Keshavarz and Roy 2010).

The current interest in these biopolymers is stimulated by the search for cost-effective production of PHAs through low cost carbon sources. In previous works of our research group we have demonstrated the capability of $C$. necator to grow using galacturonic acid (GalA) as single source of carbon, as well as using the products of acid (Locatelli et al. 2011) and enzymatic (Locatelli 2012) hydrolysis of pectin. However, the ability of C. necator to grow using the hydrolyzed extract from orange or passion fruit wastes has not been studied.

In this context, the objective of the present study was to investigate the cell growth of Cupriavidus necator using hydrolyzed extracts of orange pear and yellow passion fruit as the main carbon source.

\section{MATERIALS AND METHODS}

\section{FRUIT PROCESSING}

Yellow passion fruit (Passiflora edulis f. Flavicarpa) and orange pear (Citrus sinensis (L.) Osbeck) were obtained in a local market (Vitória de Santo Antão - PE, Brazil). Aiming to obtained material similar to the industrial wastes of orange and passion fruit, the fruits were washed and the juice extracted. After, the waste fruits (peels and bagasse) were chopped into small cubes of 1 to 2 $\mathrm{cm}$ and dried in an air circulating oven at $70{ }^{\circ} \mathrm{C}$ for 12 hours, followed by grinding and granulometric grading of 35 mesh.

\section{PHYSICO-CHEMICAL COMPOSITION OF WASTES}

Analyses of the dry residues of fruits were performed in triplicate from moisture, total fat, proteins $(\mathrm{N} \mathrm{x}$ 6.25 ), mineral residues and carbohydrates followed by analytical standards of the Adolfo Lutz Institute (ALI 2008). The fiber analysis was performed by non-enzymatic method according to Guerra et al. (2004).

\section{EXTRACTS PROCESSING}

The dried samples were submitted to extraction method according to Pinheiro (2007), which obtained the highest yield of pectin using citric acid 2.9\% (m/v) in proportion 2:100 $\left(20.0 \mathrm{~g} \mathrm{~L}^{-1}\right)$. The mixture was kept on low heat by 60 minutes, counting from the beginning of the boil and 
recovering the volume lost by evaporation. After, the material was filtered in nylon filter to remove the insoluble portion (cellulose and hemicellulose). Samples of both extracts were collected for analysis in triplicate of reducing compounds (RC) by DNS method (Miller 1959), pectins concentration (Pinheiro 2007) and esterification degree (Bochek 2001).

\section{ENZYMATIC HYDROLYSIS}

Fruit extracts were adjusted to $\mathrm{pH} 4,0$ with $\mathrm{NaOH}$ $50 \%(\mathrm{~m} / \mathrm{v})$, followed by addition of citrate buffer $(25 \mathrm{mM})$ and submitted to enzymatic hydrolysis in triplicate using polygalacturonase (EC 3.2.1.15, Sigma $\left.{ }^{\circledR}\right)$ in concentration of $10,0 \mathrm{UI} / \mathrm{g}$ of substrate, $300 \mathrm{rpm}$ of agitation for 24 hours (Locatelli 2012). The flasks were incubated in a rotary shaker incubator at $50{ }^{\circ} \mathrm{C}$ and $\mathrm{pH} 4,0$ (optimal conditions of enzyme activity, according to the supplier - Sigma $\left.{ }^{\circledR}\right)$. Samples of both fruit extracts were collected at the end process for analysis in triplicate to determination of reducing compounds (RC) by DNS method. The hydrolyzed extracts were adjusted to $\mathrm{pH} 7,0$ with $\mathrm{NaOH} 50 \%(\mathrm{~m} / \mathrm{v})$, sterilized by autoclave for 15 minutes and used in formulation of culture media.

\section{MICROORGANISM MAINTENANCE AND INOCULUM}

The strain of Cupriavidus necator was obtained from the Deutsche Sammlung von Mikroorganismen und Zellkulturen (DSMZ 545) and was maintained in the culture collection of the Department of Antibiotics of the Universidade Federal de Pernambuco (UFPEDA 0604). The culture was frequently subcultured on tubes containing nutrient agar slants, and stored at $4-8{ }^{\circ} \mathrm{C}$.

To prepare the inoculum, a loopful of the stock culture was transferred to $250 \mathrm{~mL}$ Erlenmeyer flask containing $100 \mathrm{~mL}$ of nutrient broth (NB). The microrganism was cultured for $10 \mathrm{~h}$ at $30{ }^{\circ} \mathrm{C}$ and $300 \mathrm{rpm}$. This time of cultivation was previously established for attainment of the exponential growth phase.

\section{CULTURE CONDITIONS}

C. necator was cultured in triplicate on Erlenmeyer flasks under the same conditions described previously and employing an inoculum size of 5\% $(\mathrm{v} / \mathrm{v})$. The culture medium used in this work was described by Ramsay et al. (1990) and modified by Aragão etal.(1996) and had as the main composition (g.L $\left.{ }^{-1}\right)$ : Solution 1 - nitrolactic acid (0.19), ferrous ammonium citrate (0.06), $\mathrm{MgSO}_{4} .7 \mathrm{H}_{2} \mathrm{O}(0.5)$, $\mathrm{CaCl}_{2} \cdot 2 \mathrm{H}_{2} \mathrm{O}$ (0.01); Solution $2-\mathrm{Na}_{2} \mathrm{HPO}_{4} \cdot 12 \mathrm{H}_{2} \mathrm{O}$ (8.95), $\mathrm{KH}_{2} \mathrm{PO}_{4}$ (1.5); Solution $3-\left(\mathrm{NH}_{4}\right)_{2} \mathrm{SO}_{4}$ (5.0); Solution of oligoelements $\left(1 \mathrm{~mL} . \mathrm{L}^{-1}\right)$. The composition of the oligoelements solution was (g.L $\left.{ }^{1}\right): \mathrm{H}_{3} \mathrm{BO}_{3}(3.0), \mathrm{CoCl}_{2} \cdot 6 \mathrm{H}_{2} \mathrm{O}(0.2), \mathrm{ZnSO}_{4} \cdot 7 \mathrm{H}_{2} \mathrm{O}$ (0.1), $\mathrm{MnCl}_{2} .4 \mathrm{H}_{2} \mathrm{O}(0.03), \mathrm{Na}_{2} \mathrm{MoO}_{4} .2 \mathrm{H}_{2} \mathrm{O}(0.03)$, $\mathrm{NiCl}_{2} \cdot 6 \mathrm{H}_{2} \mathrm{O}(0.02), \mathrm{CuSO}_{4} \cdot 5 \mathrm{H}_{2} \mathrm{O}(0.01)$. The extract hydrolysate from orange or passion fruit wastes (Solution 4), was added to the culture medium equivalent to substrate final concentration of $5 \mathrm{~g} . \mathrm{L}^{-1}$ (reducing compounds). The $\mathrm{pH}$ of the solutions was adjusted to 7.0 with $\mathrm{KOH}(5.0 \mathrm{M})$. The solutions were then autoclaved separately and mixed aseptically to prepare the culture media. Samples were withdrawn at intervals of 2 hours for analyses of $\mathrm{pH}$, cell concentration and reducing compounds (RC).

\section{ANALYTICAL METHODS}

Cell growth was measured using a Marconi ${ }^{\circledR}$ spectrophotometer operated at a wavelength of $600 \mathrm{~nm}$. The optical density values were correlated to the dry mass using a calibration curve. The dry mass was determined by drying the samples until constant weight at $70{ }^{\circ} \mathrm{C}$, after filtration using a $0.22 \mu \mathrm{m}$ membrane. The $\mathrm{pH}$ was monitored using a Marconi ${ }^{\circledR}$ potentiometer. Measurements of reducing compounds (RC) were performed according to the 3,5-dinitrosalicylic acid (DNS) 
method described by Miller (1959), employing glucose as the reference for construction of the calibration curve.

\section{RESULTS AND DISCUSSION}

PHYSICOCHEMICAL COMPOSITION OF ORANGE AND PASSION FRUIT WASTES

Table I shows the physicochemical composition of orange and passion fruit wastes, with the results expressed on dry weight. For orange pear peels, Ruviaro et al. (2008) found similar content of mineral residues $-4.92 \mathrm{~g} .100 \mathrm{~g}^{-1}$, total fat -2.16 g. $100 \mathrm{~g}^{-1}$ and proteins $-4.85 \mathrm{~g} .100 \mathrm{~g}^{-1}$. Rezzadori et al. (2012) found a total dietary fiber content of 60 g. $100 \mathrm{~g}^{-1}$ and carbohydrates content of 20 g.100 $\mathrm{g}^{-1}$, while in the present study the level of dietary fiber and carbohydrates was 56.4 g. $100 \mathrm{~g}^{-1}$ and 28.9 g. $100 \mathrm{~g}^{-1}$, respectively.

For the samples of passion fruit, the contents of moisture, mineral residues, protein and fat were similar to those found by Pinheiro (2007), LópezVargas et al. (2013) and Oliveira et al. (2015). As compared to other works, the total dietary fiber was low $\left(50.7 \pm 0.7\right.$ g.100 $\left.\mathrm{g}^{-1}\right)$ and the carbohydrates content was high $\left(30.7 \pm 0.6\right.$ g. $\left.100 \mathrm{~g}^{-1}\right)$. Pinheiro (2007) found a total dietary fiber content of 57.36 g. $100 \mathrm{~g}^{-1}$ and $21.28 \mathrm{~g} .100 \mathrm{~g}^{-1}$ of carbohydrates. Canteri (2010) found a total dietary fiber content of 64.10 g. $100 \mathrm{~g}^{-1}$ and $14.80 \mathrm{~g} .100 \mathrm{~g}^{-1}$ of carbohydrates and Oliveira et al. (2015) found a total dietary fiber content of 69.69 g. $100 \mathrm{~g}^{-1}$.

Pectin is a major component of the dietary fiber content for both fruit wastes. For orange wastes, the pectin content $\left(39.7 \pm 0.5 \mathrm{~g} .100 \mathrm{~g}^{-1}\right)$ is according to Rivas et al. (2008), who found $42.5 \mathrm{~g} .100 \mathrm{~g}^{-1}$. The degree of esterification (DE) of $41.0 \pm 1.3$ g.100 $\mathrm{g}^{-1}$ was higher than found by Müller-Maatsch et al. (2016), who found a value below 30.0 g. 100 $\mathrm{g}^{-1}$. Passion fruit wastes presented a low DE (26.4 $\pm 0.1 \%)$ and this result was similar to those found by Pinheiro (2007), who determined a DE of 27.69 g. $100 \mathrm{~g}^{-1}$ for this waste. The DE is the percentage of galacturonic acid subunits that are methyl esterified and varies according to the extraction conditions, $\mathrm{pH}$ and time (Oliveira et al. 2015). Pectins with DE lower than $50.0 \%$ are considered low-ester pectins (May 2000).

The results indicate high fibers value and total carbohydrates (composed mostly by RC). The passion fruit wastes contain 26.3 g. $100 \mathrm{~g}^{-1}$ of RC from 30.7 g.100 g $\mathrm{g}^{-1}$ of carbohydrates. This result was similar to reported by Uchoa et al. (2008), who found $20.56 \mathrm{~g} .100 \mathrm{~g}^{-1}$ of soluble sugars in passion fruit peels. The orange wastes presented 28.8 g.100 g ${ }^{-1}$ of RC from 29.9 g.100 $\mathrm{g}^{-1}$ of carbohydrates. Soluble sugars in orange peels varies between 38-40 wt \%, and glucose, fructose and sucrose are the main sugars, although xylose, glucooligosaccharides and uronic acids can also be found in small quantities (Rivas et al. 2008, Torrado et al. 2011). This fraction of soluble sugars is an important substrate in conversion biological process.

\section{HYDROLYZED EXTRACT OF ORANGE AND PASSION FRUIT WASTES}

Figure 1 shows the experimental results obtained for the concentration of reducing compounds (RC) of the fruit wastes extracts before and after enzymatic hydrolysis. Both extracts presented around 5 g. $\mathrm{L}^{-1}$ of $\mathrm{RC}$ before hydrolysis enzymatic (orange wastes - 5.8 g.L - $^{-1}$; passion fruit wastes - 5.2 g. $\left.\mathrm{L}^{-1}\right)$. After hydrolysis, the final concentrations of $\mathrm{RC}$ ranged 13.3 g. $\mathrm{L}^{-1}$ and 9.5 g. $\mathrm{L}^{-1}$ for orange and passion fruit wastes, respectively. Considering that the pectin content in 20.0 g. $\mathrm{L}^{-1}$ of both wastes was $39.7 \%$ for orange $\left(7.9\right.$ g. $\left.\mathrm{L}^{-1}\right)$ and $37.0 \%$ for passion fruit $\left(7.4\right.$ g.L $\left.\mathrm{L}^{-1}\right)$, the efficiencies of hydrolysis were $94.4 \%$ and $58.1 \%$, respectively.

Orange and passion fruit pectins contain in their composition uronic acids, rhamnose, arabinose, galactose, glucose, xylose, mannose, fucose (Torrado et al. 2011, Kaya et al. 2014, 
TABLE I

Physicochemical composition of orange pear and yellow passion fruit wastes.

\begin{tabular}{|c|c|c|c|c|}
\hline \multirow{2}{*}{ Parameters Physicochemical } & \multicolumn{2}{|c|}{ Orange } & \multicolumn{2}{|c|}{ Passion fruit } \\
\hline & $\left(\mathrm{g} .100 \mathrm{~g}^{-1}\right)$ & SD & $\left(\mathrm{g} .100 \mathrm{~g}^{-1}\right)$ & SD \\
\hline Moisture & 3.9 & 0.1 & 4.7 & 0.2 \\
\hline Mineral residues & 4.6 & 0.1 & 9.5 & 0.3 \\
\hline Total fat & 1.3 & 0.1 & 0.2 & 0.0 \\
\hline Proteins & 4.9 & 0.1 & 4.3 & 0.1 \\
\hline Carbohydrates $^{1}$ & 28.9 & 0.6 & 30.7 & 0.6 \\
\hline Reducing compounds (RC) & 28.8 & 0.6 & 26.3 & 0.4 \\
\hline Dietary fibers & 56.4 & 0.3 & 50.7 & 0.7 \\
\hline Pectin & 39.7 & 0.5 & 37.0 & 0.2 \\
\hline Degree, of esterification (DE) & 41.0 & 1.3 & 26.4 & 0.1 \\
\hline
\end{tabular}

SD: standard deviation; Values are expressed as g/100 g d.w.; ${ }^{1}$-Calculated by difference.

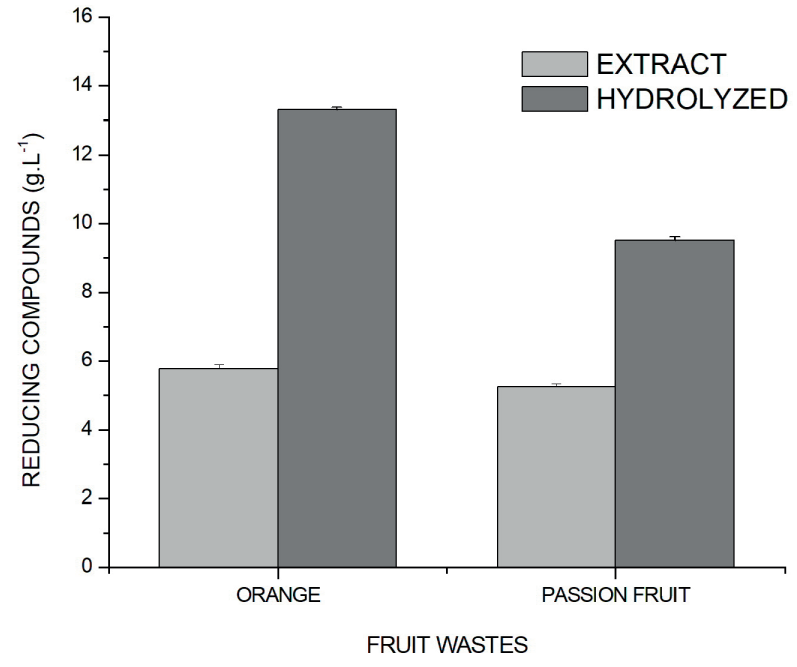

Figure 1 - Concentration of reducing sugars of the fruit wastes extracts before and after enzymatic hydrolysis using polygalacturonase (10.0 UI/g of substrate).

Müller-Maatsch et al. 2016, Seixas et al. 2014, Oliveira et al. 2015). Recent research (Table II) has demonstrated that theses fruit wastes are potentially valuable resource that can be used as substrates in cell growth of $C$. necator, mainly after enzymatic hydrolysis of pectin. C. necator is able to grow in the presence of different hydrolysis products as only carbon source, showing high metabolic activity on glucose, fructose, galactose, galacturonic acid and even furfural (a major hydrolysate derived from pentose dehydration), besides poor metabolic activity on xylose and arabinose (Yu et al. 2008).

\section{CELL GROWTH OF Cupriavidus necator}

Both the hydrolyzed extracts of fruit wastes were used separated to compose the culture media (RC concentration of 5.0 g. $\mathrm{L}^{-1}$ ) as the only carbon source, and Figure 2 shows growth behavior of C. necator using hydrolyzed extracts of orange wastes (a) and passion fruit (b). No significant difference was observed in in specific growth rate for both cultures, and the total cells concentration was higher during growth in hydrolyzed extract of orange wastes $\left(1.23 \mathrm{~g} . \mathrm{L}^{-1}\right)$ as compared to cells grown from passion fruit-based medium $(0.83$ g.L$\left.{ }^{1}\right)$. These results are consistent with the values of the biomass yield on substrate, being observed a highest $\mathrm{Y}_{\mathrm{x} / \mathrm{s}}$ value using hydrolyzed extract of orange wastes $\left(0.56 \mathrm{~g} . \mathrm{g}^{-1}\right)$. Comparing the results of yield of cell growth with those observed for others carbon sources, we can observe that orange wastes presented higher $\mu_{\mathrm{Max}}$ and $\mathrm{Y}_{\mathrm{X} / \mathrm{S}}$ than passion fruit wastes and others carbon source as glucose, fructose and inverted sugar, that are traditionally used in industrial process (Table II).

The $\mathrm{pH}$ behavior shows little variation, but a small increase is expected during cell growth of 
TABLE II

Cell growth rates of Cupriavidus necator using orange and passion fruit wastes and comparing with others carbon source.

\begin{tabular}{|c|c|c|c|c|c|c|}
\hline References & $\begin{array}{l}\text { Microbial } \\
\text { Strain }\end{array}$ & $\begin{array}{c}\text { Carbon source } \\
\text { Type }\end{array}$ & $\begin{array}{c}\text { Initial Carbon } \\
\text { concentration } \\
\left(\text { g. } \mathbf{L}^{-1}\right)\end{array}$ & $\begin{array}{c}\text { Total Biomass } \\
\text { concentration } \\
\left(\mathrm{g} \cdot \mathrm{L}^{-1}\right)\end{array}$ & $\mathbf{Y}_{\mathrm{x} / \mathrm{s}}$ & $\mu_{\mathrm{Max}}$ \\
\hline This paper & $\begin{array}{l}\text { C. necator- } \\
\text { DSM } 545\end{array}$ & $\begin{array}{c}\text { Hydrolyzed } \\
\text { extract of } \\
\text { orange wastes } \\
\text { Hydrolyzed } \\
\text { extract of } \\
\text { passion fruit } \\
\text { wastes } \\
\end{array}$ & $\begin{array}{c}5.00 \text { (in } \\
\text { reducing } \\
\text { compounds) }\end{array}$ & 1.23 & 0.56 & $0.27 h^{-1}$ \\
\hline $\begin{array}{l}\text { Lagunes and } \\
\text { Winterburn } \\
2016\end{array}$ & $\begin{array}{l}\text { C. necator H16- } \\
\text { DSM } 428\end{array}$ & $\begin{array}{l}\text { Orange juicing } \\
\text { waste }\end{array}$ & $\begin{array}{l}14.94 \text { (of } \\
\text { fructose) }\end{array}$ & 6.21 & 0.40 & $0.179 \mathrm{~h}^{-1}$ \\
\hline $\begin{array}{c}\text { Yousuf and } \\
\text { Winterburn } \\
2016\end{array}$ & C. necator $\mathrm{H} 16$ & $\begin{array}{l}\text { Date seeds } \\
\text { extract }\end{array}$ & $\begin{array}{l}10.80 \text { (of } \\
\text { fructose) }\end{array}$ & 6.30 & 0.68 & $0.13 \mathrm{~h}^{-1}$ \\
\hline \multirow{4}{*}{$\begin{array}{l}\text { Aramvash et al. } \\
2015\end{array}$} & \multirow{4}{*}{$\begin{array}{c}\text { C. necator- } \\
\text { ATCC } 17699\end{array}$} & Arabinose & \multirow{4}{*}{20.00 (of each) } & 0.96 & \multirow{4}{*}{--- } & \multirow{4}{*}{--- } \\
\hline & & Glucose & & 5.14 & & \\
\hline & & Fructose & & 4.76 & & \\
\hline & & Sucrose & & 3.92 & & \\
\hline \multirow{3}{*}{$\begin{array}{l}\text { Figueiredo et al. } \\
2014\end{array}$} & $\begin{array}{c}\text { C. necator-IPT } \\
026\end{array}$ & Residual & \multirow{3}{*}{30.00 (of each) } & $\begin{array}{l}1.91 \\
4.39\end{array}$ & \multirow{3}{*}{---} & \multirow{3}{*}{---} \\
\hline & $\begin{array}{c}\text { C. necator-IPT } \\
027\end{array}$ & $\begin{array}{l}\text { Glycerin from } \\
\text { Biosiesel }\end{array}$ & & $\begin{array}{l}1.83 \\
3.48\end{array}$ & & \\
\hline & $\begin{array}{c}\text { C. necator-IPT } \\
028\end{array}$ & Glucose & & $\begin{array}{l}0.67 \\
2.13 \\
\end{array}$ & & \\
\hline \multirow[b]{2}{*}{$\begin{array}{l}\text { Locatelli et al. } \\
\qquad 2011\end{array}$} & \multirow[b]{2}{*}{$\begin{array}{l}\text { C. necator- } \\
\text { DSM } 545\end{array}$} & $\begin{array}{l}\text { Galacturonic } \\
\text { acid }\end{array}$ & 15.00 & 0.60 & --- & --- \\
\hline & & $\begin{array}{l}\text { Pectin } \\
\text { hydrolysate }\end{array}$ & $\begin{array}{l}3.82 \text { (in } \\
\text { reducing } \\
\text { compounds) }\end{array}$ & 0.63 & 0.55 & $0.26 \mathrm{~h}^{-1}$ \\
\hline \multirow{3}{*}{ Baei et al. 2011} & \multirow{3}{*}{$\begin{array}{l}\text { C. necator- } \\
\text { DSM } 545\end{array}$} & Glucose & \multirow{3}{*}{40.00 (of each) } & \multirow[b]{3}{*}{---} & 0.53 & $0.17 \mathrm{~h}^{-1}$ \\
\hline & & Fructose & & & 0.50 & $0.125 \mathrm{~h}^{-1}$ \\
\hline & & $\begin{array}{c}\text { Sugarcane } \\
\text { Molasses } \\
\text { (Inverted sugar) }\end{array}$ & & & 0.55 & $0.42 \mathrm{~h}^{-1}$ \\
\hline $\begin{array}{l}\text { Dalcanton et al. } \\
2010\end{array}$ & $\begin{array}{l}\text { C. necator- } \\
\text { DSM } 545\end{array}$ & $\begin{array}{l}\text { Rice starch } \\
\text { hydrolysate }\end{array}$ & $\begin{array}{l}30.00 \text { (in } \\
\text { reducing sugars) }\end{array}$ & 7.69 & --- & $0.238 \mathrm{~h}^{-1}$ \\
\hline \multirow{2}{*}{$\begin{array}{l}\text { Cavalheiro et al. } \\
2009\end{array}$} & \multirow{2}{*}{$\begin{array}{l}\text { C. necator- } \\
\text { DSM } 545\end{array}$} & $\begin{array}{l}\text { Waste glycerol } \\
\text { (GRP) }\end{array}$ & \multirow{2}{*}{---} & 68.8 & 0.45 & $0.15 \mathrm{~h}^{-1}$ \\
\hline & & $\begin{array}{l}\text { Commercial } \\
\text { Glycerol (PG) }\end{array}$ & & 82.5 & 0.37 & $0.12 \mathrm{~h}^{-1}$ \\
\hline \multirow{4}{*}{$\begin{array}{l}\text { Marangoni et al. } \\
2001\end{array}$} & \multirow{4}{*}{$\begin{array}{c}\text { R. eutropha- } \\
\text { DSM } 545 \\
\text { (Nowdays } C \text {. } \\
\text { necator) }\end{array}$} & Inverted sugar & \multirow{4}{*}{20.00 (of each) } & \multirow{4}{*}{--- } & \multirow{4}{*}{---} & $0.26 \mathrm{~h}^{-1}$ \\
\hline & & Glucose & & & & $0.23 \mathrm{~h}^{-1}$ \\
\hline & & Fructose & & & & $0.21 \mathrm{~h}^{-1}$ \\
\hline & & Galactose & & & & $0.13 \mathrm{~h}^{-1}$ \\
\hline
\end{tabular}

$\mathrm{Y}_{\mathrm{S} / \mathrm{X}}$ - cell yield coefficient ( $\mathrm{g}$ cells / $\mathrm{g}$ substrate).

Source: The authors. 


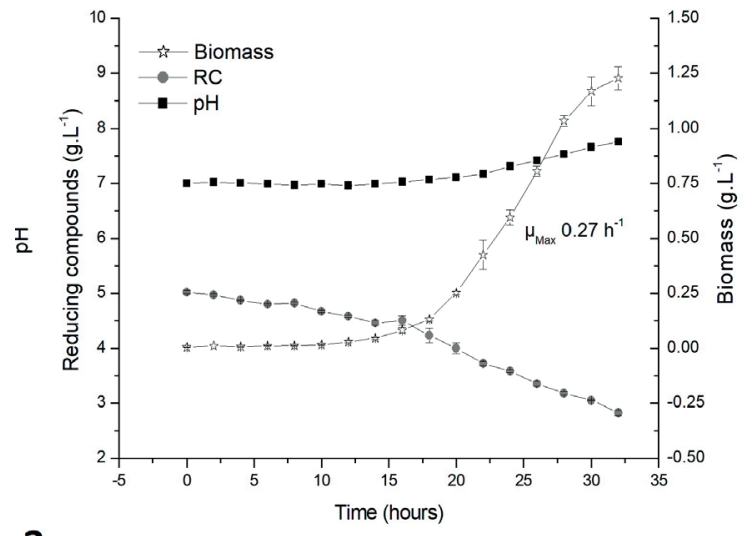

a

Figure 2 - Cell growth of Cupriavidus necator using hydrolyzed extracts of orange wastes (a), and passion fruit (b), as the only carbon sources.

C. necator (Locatelli et al. 2011, Aramvash et al. 2015). The RC variation shows a decrease during cell growth, which indicate the metabolic activity on carbon source, but at end process we can note a residual $\mathrm{RC}$ of $2.83 \mathrm{~g} . \mathrm{L}^{-1}$ to extracts of orange wastes and, 3.15 g.L. $\mathrm{L}^{-1}$ to extracts of passion fruit wastes, that were not metabolized by $C$. necator. Others authors (Baei et al. 2009, 2011, Locatelli et al. 2011, Lagunes and Winterburn 2016) also observed this phenomenon. This residual RC can be explained by presence of oligomers (di or trisaccharides) that had reducing terminal, but can not be used for cell growth of $C$. necator because absence of hydrolytic enzymes for utilization of these oligosaccharides (Yu et al. 2008).

\section{CONCLUSIONS}

The orange and passion fruit wastes presented high fibers and carbohydrates concentration (mainly soluble sugars), displaying great potential to be used as substrates in biological conversion processes.

The hydrolysis process with the enzyme polygalacturonase (EC 3.2.1.15, Sigma ${ }^{\circledR}$ ) in concentration of $10,0 \mathrm{UI} / \mathrm{g}$ of substrate, $300 \mathrm{rpm}$ of agitation for 24 hours was more efficient for orange wastes than passion fruit wastes, showing more $90 \%$ of hydrolysis to orange wastes.

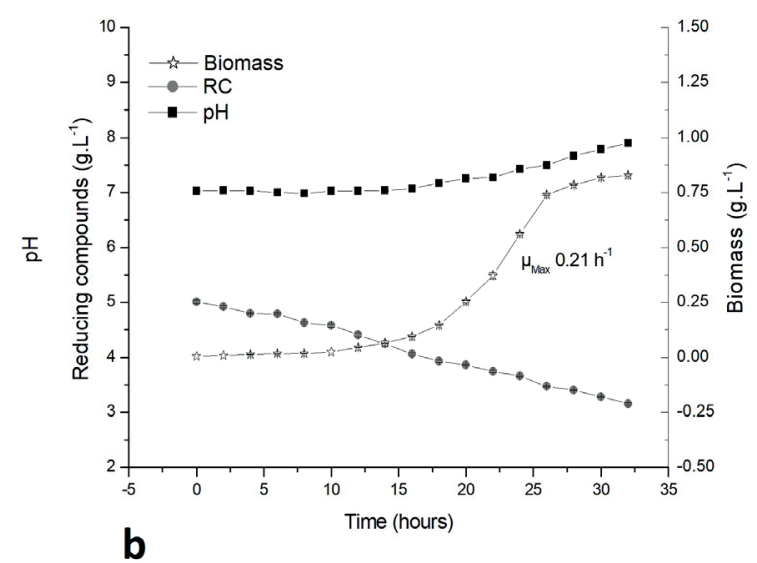

b
C. necator showed good metabolic activity on the hydrolyzed of orange and passion fruit wastes, with satisfactory growth rates when comparing to others carbon sources. However the hydrolyzed from orange wastes presented higher growth rates, which makes possible its use as inexpensive carbon source for cell growth of $C$. necator.

\section{ACKNOWLEDGMENTS}

The authors are very grateful to the financial support from the Fundação de Amparo à Ciência e Tecnologia do Estado de Pernambuco (FACEPE), for the scholarship of master's degree.

\section{AUTHOR CONTRIBUTIONS}

All authors conceived and planned the experiments. G.O. Locatelli carried out the experiments. L. Finkler and C.L.L. Finkler contributed to samples preparation. All authors contributed to the interpretation of the results. G.O. Locatelli took the lead in writing the manuscript. All authors provided critical feedback and contributed to the final version of the manuscript.

\section{REFERENCES}

ALI - ADOLFO LUTZ INSTITUT. 2008. Métodos físicoquímicos para análise de alimentos. In: Zenebon $\mathrm{O}$, 
Pascuet NS and Tiglea P (Eds), São Paulo: Instituto Adolfo Lutz, 1020 p.

ANJUM A, ZUBER M, ZIA KM, NOREEN A, ANJUM MN AND TABASUM S. 2016. Review: Microbial production of polyhydroxyalkanoates (PHAs) and its copolymers: A review of recent advancements. Int J Biol Macromol 89: 161-174.

ARAGÃO GMF, LINDLEY ND, URIBELARREA JL AND PAREILLEUX A. 1996. Maintaining controlled residual growth capacity increases the production of polyhydroxyalkanoate copolymers by A. eutrophus. Biotechnol Lett 18: 937-942.

ARAMVASH A, SHAHABI ZA, AGHJEH DS AND GHAFARI MD. 2015. Statistical physical and nutrient optimization of bioplastic polyhydroxybutyrate production by Cupriavidus necator. Int J Environ Sci Technol 12: 2307-2316.

BAEI MS, NAJAFPOUR GD, YOUNESI H, TABANDEH F AND EISAZADEH H. 2009. Poly(3-hydroxybutyrate) Synthesis by Cupriavidus necator DSMZ 545 Utilizing Various Carbon Sources. World Appl Sci J 7: 157-161.

BAEI MS, NAJAFPOUR GD, YOUNESI H, TABANDEH F, ISSAZADEH H AND KHODABANDEH M. 2011. Growth kinetic parameters and biosynthesis of polyhydroxybutyrate in Cupriavidus necator DSMZ 545 on selected substrates. Chem Ind Chem Eng Q 17: 1-8.

BOCHEK AM, ZABIVALOVA NM AND PETROPAVLOVSKIIK GA. 2001. Determination of the esterification degree of polygalacturonic acid. Russ J Appl Chem 74: 796-799.

CANTERI MHG. 2010. Caracterização Comparativa Entre Pectinas Extraídas do Pericarpo de Maracujá-Amarelo (Passiflora edulis f. flavicarpa). Tese de Doutorado. Curso de Pós-Graduação em Tecnologia de Alimentos. Universidade Federal do Paraná, Curitiba, 162 p.

CASTILHO LR, MITCHELL DA AND FREIREC DMG. 2009. Production of polyhydroxyalkanoates (PHAs) from waste materials and by-products by submerged and solidstate fermentation. Bioresour Technol 100: 5996-6009.

CAVALHEIRO JMBT, DE ALMEIDA MCMD, GRANDFILS C AND DA FONSECA MMR. 2009. Poly(3hydroxybutyrate) production by Cupriavidus necator using waste glycerol. Process Biochem 44: 509-515.

DALCANTON F, IENCZAK JL, FIORESE ML AND ARAGÃO GMF. 2010. Produção de poli(3-hidroxibutirato) por Cupriavidus necator em meio hidrolisado de amido de arroz com suplementação de óleo de soja em diferentes temperaturas. Quim Nova 33: 552-556.

DARROS-BARBOSA R AND CURTOLO JE. 2005. Produção industrial de suco e subprodutos cítricos. In: Junior Mattos D, De Negri JD, Pio RM and Pompeu Junior J (Eds), Citros, Campinas, Instituto Agronômico e Fundag, 929 p.
FERRARI RA, COLUSSI F AND AYUB RA. 2004. Caracterização de subprodutos da industrialização do maracujá - Aproveitamento das sementes. Rev Bras Frutic 26: 101-102.

FIGUEIREDO TVB, CAMPOS MI, SOUZA LS, SILVA JR AND DRUZIANA JI. 2014. Production and characterization of polyhydroxyalkanoates obtained by fermentation of crude glycerin from biodiesel. Quim Nova 37: 1111-1117.

GARCIA-CASTELLO EM, MAYOR L, CHORQUES S, ARGÜELLES A, VIDAL-BROTÓNS D AND GRAS ML. 2011. Reverse osmosis concentration of press liquid from orange juice solid wastes: flux decline mechanisms. J Food Eng 106: 199-205.

GUERRA NB, DAVID PRBS, MELO DD, VASCONCELOS ABB AND GUERRA MRM. 2004. Modifications in the gravimetric non enzymatic method for determination of soluble and insoluble dietary fiber in fruits. Rev Nutr 17: 45-52.

IBGE - INSTITUTO BRASILEIRO DE GEOGRAFIA E ESTATÍSTICA. Produção Agrícola Municipal. 2016. Disponível em: https://biblioteca.ibge.gov.br/index.php/ biblioteca-catalogo?view $=$ detalhes\&id $=766$. Acesso em 16 de janeiro de 2017.

KAYA M, SOUZA AG, CRÉPEAU MJ, SORENSEN SO AND RALET MC. 2014. Characterization of citrus pectin samples extracted under different conditions: influence of acid type and pH of extraction. Ann Bot 114: 1319-1326.

KESHAVARZ T AND ROY I. 2010. Polyhydroxyalkanoates: bioplastics with a green agenda. Curr Opin Microbiol 13: 321-326.

LAGUNES FG AND WINTERBURN JB. 2016. Effect of limonene on the heterotrophic growth and polyhydroxybutyrate production by Cupriavidus necator H16. Bioresour Technol 221: 336-343.

LAI SM, DON TM AND HUANG YC. 2005. Preparation and properties of biodegradable thermoplastic starch/poly (hydroxybutyrate) blends. J Appl Polym Sci 100: 23712379.

LOCATELLI GO. 2012. Estudo das condições de hidrólise da pectina para uso como substrato na produção de polihidroxialcanoatos. Dissertação de Mestrado, Curso de Pós-Graduação em Biotecnologia Industrial. Universidade Federal de Pernambuco - UFPE, Recife, 105 p. (Unpublished).

LOCATELLI GO, SILVA GD, FINKLER L AND FINKLER CLL. 2011. Acid hydrolysis of pectin for cell growth of Cupriavidus necator. Biotechnol 1: 1-8.

LÓPEZ-VARGAS JH, FERNÁNDEZ-LÓPEZ J, PÉREZÁlVAREZ JÁ AND VIUDA-MARTOS M. 2013. Chemical, physico-chemical, technological, antibacterial and antioxidant properties of dietary fiber powder 
obtained from yellow passion fruit (Passiflora edulis Var. flavicarpa) co-products. Food Res Int 51: 756-763.

MARANGONI C, FURIGO JUNIOR A AND ARAGÃO GMF. 2001. The influence of substrate source on the growth of Ralstonia eutropha, aiming at the production of polyhydroxyalkanoates. Braz J Chem Eng 18: 175-180.

MAY CD. 2000. Pectins. In: Phillips GO and Williams PA (Eds), Handbook of Hydrocolloids. New York, 450 p.

MILLER GL. 1959. Use of dinitrosalicylic acid reagent for determination of reducing sugar. Anal Chem 31: 426-428.

MÜLLER-MAATSCH J, BENCIVENNI M, CALIGIANI A, TEDESCHI T, BRUGGEMAN G, BOSCH M, PETRUSAN J, DROOGENBROECK BV, ELST K AND SFORZA S. 2016. Pectin content and composition from different food waste streams. Food Chem 201: 37-45.

OLIVEIRA CF, GIORDANI D, GURAK PD, CLADERAOLIVERA F AND MARCZAK LDF. 2015. Extraction of pectin from passion fruit peel using moderate electric field and conventional heating extraction methods. Innov Food Sci Emerg Technol 29: 201-208.

PINHEIRO ER. 2007. Pectina da casca do maracujá amarelo (Passiflora edulis flavicarpa): Otimização da extração com ácido cítrico e caracterização físico-química. Dissertação de Mestrado. Universidade Federal de Santa Catarina, Florianópolis, 79 p. (Unpublished).

POIRIER Y, NAWRATH C AND SOMERVILLE C. 1995. Production of polyhydroxyalkanoates, a family of Biodegradable plastics and elastomers, in bacterial and plant. Biotechnol 13: 142-150.

RAMSAY BA. 1994. Physiological factor affecting PHA production. Physiology, kinetics, production and use of biopolymers. Proceedings Austria, p. 9-17.

RAMSAY BA, LOMALIZA K, CHAVARIE C, DUBE B, BATAILLE P AND RAMSAY JA. 1990. Production of poly-( $\beta$-hydroxybutyric-co- $\beta$-hydroxyvaleric) acids. Appl Environ Microbiol 56: 2093-2098.
REZZADORI K, BENEDETTI S AND AMANTE ER. 2012. Proposals for the residues recovery: Orange waste as raw material for new products. Food Bioprod Process 90: 606614.

RIVAS B, TORRADO A, TORRES P, CONVERTI A AND DOMINGUÉX JM. 2008. Submerged Citric Acid Fermentation on Orange Peel Autohydrolysate. J Agric Food Chem 56: 2380-2387.

RUVIARO L, NOVELLO D, ALMEIDA JM AND QUINTILIANO DA. 2008. Análise sensorial de sobremesa acrescida a farelo de casca e bagaço de laranja entre universitários de Guarapuava (PR). Rev Salus 2: 41-50.

SEIXAS FL, FUKUDA DL, TURBIANI FRB, GARCIA PS, PETKOWICZ CLO, JAGADEVAN S AND GIMENES ML. 2014. Extraction of pectin from passion fruit peel (Passiflora edulis f. flavicarpa) by microwave-induced heating. Food Hydrocolloids 38: 186-192.

TORRADO AM, CORTÉS S, SALGADO JM, MAX B, RODRÍGUEZ N, BIBBINS BP, COVERTI A AND DOMÍNGUEZ JM. 2011. Citric acid production from orange peel wastes by solid-state fermentation. Braz $\mathrm{J}$ Microbiol 42: 394-409.

UCHOA AMA, COSTA JMC, MAIA GA, SILVA EMC, CARVALHO AFFU AND MEIRA TR. 2008. Physicochemical Parameters and Crude and Dietary Fiber Content of Edible Powders From Tropical Fruit Residues. Segurança Alimentar e Nutricional 15: 58-65.

WANG Y, YIN J AND CHEN GQ. 2014. Polyhydroxyalkanoates, challenges and opportunities. Curr Opin Biotechnol 30: 59-65.

YOUSUF RG AND WINTERBURN JB. 2016. Date seed characterisation, substrate extraction and process modelling for the production of polyhydroxybutyrate by Cupriavidus necator. Bioresour Technol 222: 242-251.

YU J AND STAHL H. 2008. Microbial utilization and biopolyester synthesis of bagasse hydrolysates. Bioresour Technol 99: 8042-8048. 